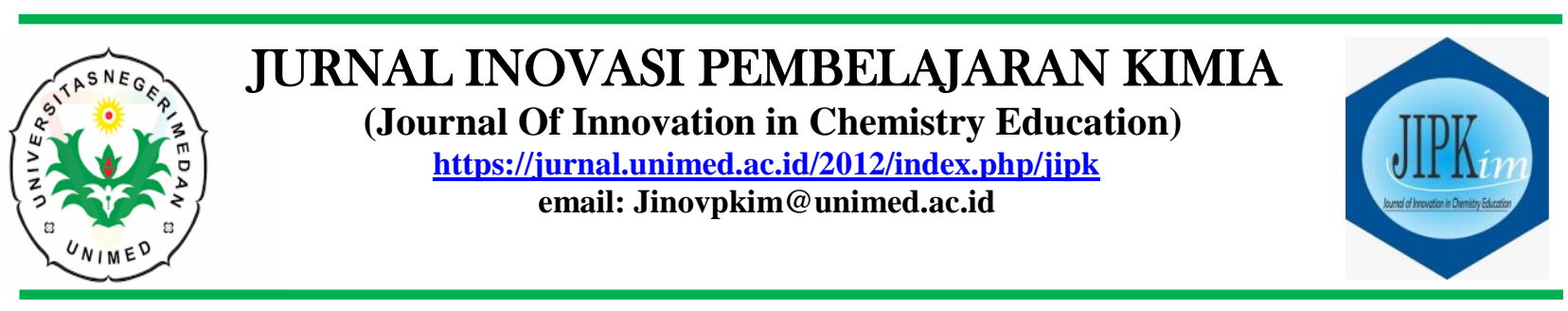

$\begin{array}{ll}\text { Masuk } & : 25 \text { Februari } 2021 \\ \text { Revisi } & : 15 \text { April } 2021 \\ \text { Diterima } & : 20 \text { April } 2021 \\ \text { Diterbitkan } & : 21 \text { April } 2021 \\ \text { Halaman } & : 56-65\end{array}$

\title{
Pengembangan Bahan Ajar Kimia Berbasis Proyek dengan Multimedia Pada Materi Alkena di Sekolah Menengah Atas
}

\author{
Jamalum Purba ${ }^{1 *}$, Rolian Ade Fitri ${ }^{2}$ \\ ${ }^{1,2}$ Program Studi Pendidikan Kimia, Universitas Negeri Medan, Medan \\ *Alamat Korespondensi: jamalum@unimed.ac.id
}

\begin{abstract}
This study aims to obtain: project-based teaching materials with multimedia that have met the criteria for content, language, presentation, and graphic eligibility according to the National Education Standards Agency and student responses to aspects of the appearance, material, and benefits of projectbased teaching materials on Alkena material. The type of research used is Research and Development $(R \& D)$ which has been modified as needed. This research was carried out in several stages, namely syllabus analysis according to the current curriculum, book and multimedia analysis by researchers, design and development of teaching materials and multimedia, validation of teaching materials by lecturers and teachers, validation of multimedia by lecturers, and then the teaching materials developed were responded by students. The average result of the validation by lecturers and teachers is 3.67 which means valid. The average result of multimedia validation is 3.77 which means valid. The average percentage level of student satisfaction with project-based teaching materials with multimedia that has been developed is $90.33 \%$. So it can be concluded that project-based teaching materials with multimedia on alkenes are valid and do not need to be revised. Based on the high student response, it means that students like the multimedia teaching materials.
\end{abstract}

Keywords: Development, project-based teaching materials, BSNP instruments, alkenes, validation of teaching materials and multimedia.

\section{PENDAHULUAN}

Pendidikan IPA memiliki peranan penting dalam rangka meningkatkan mutu pendidikan. Dalam hal ini, kita ketahui kimia merupakan bagian dari pelajaran IPA yang pada hakekatnya merupakan pengetahuan yang berdasarkan fakta, hasil pemikiran dan produk hasil penelitian para ahli, kemudian untuk perkembangan ilmu kimia diarahkan pada metode ilmiah, sikap ilmiah, dan produk ilmiah yang di miliki siswa dan akhirnya bermuara pada peningkatan hasil belajar siswa. Kimia dapat dijumpai dalam kehidupan sehari-hari namun tidak sedikit siswa yang menganggap kimia sebagai ilmu yang kurang menarik. Hal ini terjadi karena eratnya hubungan kimia dengan ide-ide atau konsepkonsep abstrak yang membutuhkan penalaran tinggi (Handono Warih et al., 2015). Siswa diketahui memiliki beberapa permasalahan yaitu dalam memahami materi Alkena diantaranya siswa belum bisa menentukan rantai utama dan rantai cabang dalam 


\section{Jamalum Purba dan Rolian Ade Fitri \\ Jurnal Inovasi Pembelajaran Kimia (Journal Of Innovation in Chemistry Education) Volume 3, Nomor I, April 2021 \\ Pengembangan Bahan Ajar Kimia Berbasis Proyek dengan Multimedia Pada Materi Alkena di Sekolah Menengah Atas}

menuliskan tatanama senyawa alkena sehingga siswa kurang tepat dalam memberikan nama dari senyawa alkena tersebut kemudian siswa juga masih belum mampu dalam menuliskan isomer dari senyawa alkena. Hal itu terjadi karena siswa cenderung pasif dan kurang memperhatikan gurunya, serta tidak adanya keinginan siswa untuk bertanya kepada guru tentang materi yang belum dipahami. Selain itu, siswa juga mudah merasa bosan ketika proses pembelajaran berlangsung. Sehingga prestasi belajar siswa kurang memuaskan.

Untuk menumbuhkan keaktifan dan kreatifitas siswa dalam proses pembelajaran, maka guru diharapkan untuk mengembangkan model pembelajaran yang mengubah model mengajar berpusat pada guru (teacher centred) menjadi pembelajaran berpusat pada siswa (student centred). Salah satunya dengan belajar menggunakan bahan ajar berbentuk modul yang tujuannya agar siswa dapat belajar secara mandiri karena tanpa sumber belajar maka tidak mungkin dapat terjadi kegiatan belajar mengajar yang baik.

Dari beberapa sumber bahan ajar yang telah dianalisis oleh peneliti mengenai materi hidrokarbon, hampir semua buku lebih detail menjelaskan materi alkana. Sementara untuk alkena dan alkuna tidak begitu dibahas secara rinci atau hanya berupa poin-poin sederhana. Kemudian beberapa buku yang dianalisis juga belum menjelaskan terkait sumber dan kegunaan dari senyawa hidrokarbon tersebut. Sehingga siswa kurang memahami materi hidrokarbon secara keseluruhan bahkan beberapa dari mereka kebingungan ketika diberikan latihan mengenai materi alkena. Menurut (Mawar et al., 2019) mengatakan bahwa beberapa siswa masih terdapat kesalahan dalam memberikan nama senyawa hidrokarbon baik itu jenuh dan tak jenuh.

Salah satu penyebab dari rendahnya hasil belajar siswa dalam pelajaran tersebut dikarenakan oleh kurangnya penggunaan bahan ajar dan media pembelajaran dalam menyampaikan materi pelajaran. Menurut Aqdwirida dalam (Nurrita, 2018), Kurikulum 2013 adalah sebuah kurikulum yang mengutamakan pemahaman, bakat, dan pendidikan berkarakter, selain itu siswa juga dituntut untuk paham akan materi, aktif berdiskusi dan presentasi serta memiliki sikap disiplin yang tinggi. Dengan kurikulum 2013 pada era digital ini menuntut guru agar lebih bisa menjadikan pembelajaran yang berpusat pada peserta didik dan menempatkan guru sebagai motivator dan fasilitator, dimana peserta didik dituntut mandiri dalam pembelajaran. Menurut Shaleh dalam (Andi Achmad, 2017), Kegiatan pembelajaran senantiasa dipengaruhi oleh beberapa faktor mulai dari kompetensi dasar, materi atau bahan ajar, sumber belajar, media dan fasilitas belajar, peserta didik yang belajar dan pendidik yang mengelola pembelajaran.

Bahan ajar merupakan bagian penting dalam pembelajaran karena dapat membantu kelancaran belajar siswa. Menurut Direktorat Pembinaan Sekolah Menengah dan Atas dalam (Singarimbun et al., 2015), Bahan ajar adalah seperangkat materi yang disusun secara sistematis untuk membantu guru/instruktur dalam proses kegiatan belajar mengajar dan memungkinkan peserta didik untuk belajar. Selain itu menurut Sutiani dkk dalam (Panggabean \& Harahap, 2020), Bahan ajar adalah salah satu komponen untuk meningkatkan keterampilan siswa dimana tingginya tingkat keterampilan berpikir yang merupakan ilmu sebagai cara berpikir, dan sikap yang merupakan aspek interaksi antara sains, teknologi, dan masyarakat.

Selama ini, Bahan ajar yang biasanya tersedia di sekolah hanya berupa buku teks dimana dalam setiap mata pelajaran setiap siswa memiliki satu buku yang dipinjam di perpustakaan. Namun, ada juga beberapa siswa yang membeli buku secara mandiri untuk mendapatkan referensi materi yang berbeda. Dengan alasan agar lebih memahami materi karena terkadang buku yang dibagikan bahasanya kurang dipahami siswa atau sulit untuk dicerna oleh siswa. Jika hal ini terus dibiarkan, maka siswa akan mengalami kesulitan dalam belajar khususnya dalam menentukan isomer dan memberikan nama dari suatu senyawa sehingga siswa mengalami 
kesulitan untuk memahami materi-materi pada subbab selanjutnya yang berhubungan dengan tata nama senyawa dan juga isomer. Selain itu kemampuan siswa dalam menyerap suatu pelajaran juga berbeda-beda sehingga berpengaruh pada pencapaian hasil belajar kimia. Hal itulah yang menjadi dasar bahwa penggunaan bahan ajar berbasis proyek menarik untuk digunakan dalam pembelajaran khususnya pada materi alkena. Karena bahan ajar berbasis proyek yang menarik pada materi alkena ini sangat dibutuhkan agar siswa dapat memahami materi tersebut dengan mudah bukan hanya tatanama, reaksi, dan isomer saja namun pembuatan, sumber hingga kegunaannya dalam kehidupan.

Selain minimnya bahan ajar, model pembelajaran juga harus dipertimbangkan dalam kegiatan belajar. Salah satu model pembelajaran yang dapat memfasilitasi peserta didik dalam memecahkan masalah adalah model pembelajaran berbasis proyek (Project Based Learning). Menurut Nurfitriyani dalam (Purba \& Siregar, 2020), Pembelajaran berbasis proyek (PjBL) merupakan penerapan pembelajaran aktif yang memiliki potensi yang amat besar untuk membuat pengalaman belajar yang lebih menarik dan bermakna. Pembelajaran berbasis proyek (PjbL) merupakan pembelajaran yang berpusat pada peserta didik dan menempatkan guru sebagai motivator dan fasilitator, dimana peserta didik dituntut mandiri dalam pembelajaran. PjBL mengarahkan peserta didik dalam memecahkan masalah secara langsung serta penyelesaiannya melibatkan kerja proyek yang secara tidak langsung peserta didik menjadi aktif dan dilatih untuk bertindak maupun berpikir kreatif (Suranti et al., 2017).

Menurut (Sitaresmi et al., 2017), Pembelajaran berbasis proyek adalah metode pembelajaran yang memberikan kesempatan guru untuk mengelola pembelajaran di kelas dengan melibatkan kerja proyek. Dimana dengan penerapan metode project based learning ini, siswa dituntut untuk dapat meningkatkan aktivitas dalam kegiatan belajar di kelas. Aktivitas ini tidak hanya dilihat dari keaktifan siswa dalam bertanya maupun menjawab pertanyaan dari guru. Akan tetapi, aktivitas belajar yang dimaksud disini adalah keseluruhan kegiatan belajar siswa di dalam kelas yang dapat menunjang rangkaian proses kegiatan metode project based learning pada materi sistem periodik unsur. Melalui pengerjaan proyek, siswa akan menjadi lebih aktif untuk berusaha menyelesaikan masalah yang ada dan menuangkan hasilnya kedalam sebuah produk, sehingga hal ini dapat meningkatkan pemahaman siswa terhadap materi tersebut.

Untuk

memaksimalkan pengembangan bahan ajar (modul) tersebut sebagai usaha untuk meningkatkan pemahaman siswa dalam materi alkena. Peneliti juga menambahkan media pembelajaran yang mendukung untuk tugas proyek tersebut karena penggunaan media pembelajaran juga sangat penting terhadap pembelajaran. Selain membaca modul, siswa juga dituntut untuk memperhatikan media yang sejalan dengan tugas proyek dalam modul tersebut. Harapannya dengan adanya bahan ajar berbasis proyek dengan multimedia (media pembelajaran) mampu membuat siswa lebih belajar mandiri mengenai materi alkena. Dengan bahan ajar yang dibuat tujuannya untuk pemahaman siswa secara teoritis serta multimedia tujuannya untuk memahami tugas proyek atau menggali informasi terkait yang ada pada media tersebut.

Oleh karena itu, berdasarkan beberapa permasalahan di atas, peneliti akan melakukan penelitian di SMA Negeri 1 Panyabungan dengan judul "Pengembangan Bahan Ajar Berbasis Proyek dengan Multimedia pada Materi Alkena di Sekolah Menengah Atas".

\section{KAJIAN LITERATUR}

Menurut (Rati et al., 2017), Model pembelajaran berbasis proyek merupakan suatu model pembelajaran yang menyangkut pemusatan pertanyaan dan masalah bermakna, pemecahan masalah, pengambilan keputusan, proses pencarian berbagai sumber, pemberian kesempatan kepada anggota untuk 
bekerja secara kolaborasi, dan menutup dengan presentasi produk nyata. Model pembelajaran berbasis proyek berfokus pada konsep dan prinsip inti sebuah disiplin, memfasilitasi mahasiswa untuk berinvestigasi, pemecahan masalah, dan tugas-tugas bermakna lainnya, berpusat pada siswa (students centered) dan menghasilkan produk nyata. Pembelajaran berbasis proyek memiliki potensi yang besar untuk memberikan pengalaman belajar yang lebih menarik dan bermakna bagi siswa. Sedangkan ciri pembelajaran berbasis proyek menurut Center for Youth Development and Education Boston yaitu: 1) Siswa mengambil keputusan sendiri dalam kerangka kerja yang telah ditentukan bersama sebelumnya. 2) Siswa berusaha memecahan sebuah masalah atau tantangan yang tidak memiliki satu jawaban pasti. 3) Siwa didorong untuk berfikir kritis, memecahkan masalah, berkolaborasi, serta mencoba berbagai bentuk komunikasi. 4) Siswa bertanggung jawab mencari dan mengelola sendiri informasi yang mereka kumpulkan. 5) Evaluasi dilakukan secara terusmenerus selama proyek berlangsung. 6) Siswa secara reguler merefleksikan dan merenungi apa yang telah mereka lakukan, baik proses maupun hasilnya.

Menurut The George Lucas Educational Foundation dalam (Sutirman, 2013), langkah-langkah Project Based Learning yaitu dimulai dengan pertanyaan esensial (Pembelajaran dimulai dengan pertanyaan esensial, yaitu pertanyaan yang mendorong siswa untuk melakukan suatu aktivitas); membuat desain rencana proyek (Siswa dengan pendampingan dari guru membuat desain rencana proyek yang akan dilakukan. Rencana proyek ditentukan oleh siswa sendiri mengacu kepada pertanyaan esensial yang telah dikemukakan sebelumnya); membuat jadwal (Guru dan siswa secara kolaboratif menyusun jadwal pelaksanaan kegiatan pembelajaran. Aktivitas pada tahap ini antara lain: (1) membuat timeline untuk menyelesaikan proyek, (2) membuat deadline penyelesaian proyek, (3) mengarahkan siswa agar merencanakan cara yang baru, (4) mengarahkan siswa ketika mereka membuat cara yang tidak berhubungan dengan proyek, dan (5) meminta siswa untuk memberi alasan tentang cara yang dipilih); memantau siswa dan kemajuan proyek (Guru bertanggung jawab memantau kegiatan siswa selama menyelesaikan proyek untuk mengetahui kemajuan pelaksanaan proyek dan mengantisipasi hambatan yang dipilih siswa); menilai hasil (Penilaian dilakukan untuk mengukur ketercapaian standar, mengevaluasi kemajuan masingmasing siswa, memberi umpan balik, tentang tingkat pemahaman yang sudah dicapai, dan menjadi bahan pertimbangan dalam menyusun strategi pembelajaran berikutnya); sampai refleksi dan evaluasi (Pada akhir pembelajaran, guru dan siswa melakukan refleksi terhadap aktivitas dan hasil proyek yang sudah dijalankan. Proses refleksi dilakukan secara individu maupun kelompok. Pada tahap ini, peserta didik diminta untuk mengungkapkan perasaan dan pengalamannya selama menyelesaikan tugas proyek yang ada). Menurut (Purba et al., 2019), proyek-proyek yang terintegrasi dalam pembelajaran bertujuan untuk memperkuat siswa dengan pengetahuan dan keterampilan yang memadai melalui implementasi teori dalam praktek dengan contoh kontekstual. Dengan proyek ini diyakini mampu memotivasi siswa dalam proses pembelajaran sekaligus memaksimalkan keterlibatan siswa dalam kegiatan pembelajaran.

\section{METODE}

Peneltian ini dilakukan di dua tempat. Yang pertama Jurusan Kimia Unimed dan yang kedua SMA Negeri 1 Panyabungan mulai dari bulan Oktober - Desember 2020. Jenis penelitian yang digunakan adalah Research and Development (R\&D) dengan model ADDIE yang dimodifikasi sesuai kebutuhan peneliti yaitu sampai tahap pengembangan.

\section{Subjek dan Objek}

Subjek pada penelitian ini adalah (1) 5 orang dosen jurusan Kimia Universitas Negeri Medan dimana sebanyak 3 orang dosen KDBK Kimia Organik FMIPA UNIMED sebagai validator ahli terhadap bahan ajar berbasis proyek yang akan dikembangkan dan 
sebanyak 2 orang dosen Kimia FMIPA UNIMED sebagai validator ahli terhadap multimedia yang akan dikembangkan. (2) 5 orang guru mata pelajaran Kimia SMA N 1 Panyabungan sebagai validator ahli terhadap bahan ajar berbasis proyek dengan multimedia yang akan dikembangkan. (3) 1 Kelas XII IPA 1 SMA N 1 Panyabungan. Objek dalam penelitian ini adalah bahan ajar berbasis proyek dengan multimedia pada materi Alkena Kelas XI IPA di SMA, namun bahan ajar berbasis proyek dengan multimedia yang dikembangkan akan di respon oleh 20 orang siswa kelas XII IPA di SMA N 1 Panyabungan.

\section{Teknik Analisis Data}

Data yang diperoleh dari penelitian adalah berupa data kualitatif dan data kuantitatif. Data kualitatif diperoleh dari penilaian / saran perbaikan validator (dosen dan guru) terhadap bahan ajar berbasis proyek dan multimedia yang diperoleh dari jawaban angket yang berisi penilaian Badan Standar Nasional Pendidikan, sedangkan data kuantitatif diperoleh dari analisis data dengan mengolah masing-masing data dari lembar validasi oleh validator dimana data dianalisis dengan menggunakan analisis deskriptif.

Analisis deskriptif persentasi digunakan untuk mendeskripsikan persentase masing-masing variabel. Data yang diperoleh berdasarkan angket validasi bahan ajar akan diolah dengan cara statistik deskriptif (Suharsimi, 2013).

Skala penilaian yang digunakan pada angket kelayakan Badan Standar Nasional Pendidikan (BSNP) yang dimodifikasi adalah 1 sampai 4, dimana 1 sebagai skor terendah dan 4 sebagai skor tertinggi. Teknik analisis data yang digunakan untuk menganalisis data hasil validasi dari dosen adalah teknik rata rata. Rumus yang digunakan untuk menghitung data hasil pengisian angket dengan rumus:

$$
\bar{X}=\frac{\Sigma X}{n}
$$

Dengan:

$\bar{X} \quad=$ nilai rata-rata
$\Sigma \mathrm{X} \quad=$ jumlah jawaban penilaian validator /subjek uji

$\mathrm{N} \quad=$ jumlah validator/subjek uji

Kriteria validitas analisis rata-rata yang digunakan dapat dilihat pada Tabel 1.

Tabel 1. Kriteria Validitas Untuk Analisis Rata-Rata Bahan Ajar

\begin{tabular}{ll}
\hline Rata-rata & \multicolumn{1}{c}{ Kriteria Validitas } \\
\hline $3,26-4,00$ & $\begin{array}{l}\text { Valid dan tidak perlu direvisi (sangat } \\
\text { layak) }\end{array}$ \\
$2,51-3,25$ & $\begin{array}{l}\text { Cukup valid dan tidak perlu direvisi } \\
\text { (layak) }\end{array}$ \\
$1,76-2,50$ & $\begin{array}{l}\text { Kurang valid dan sebagian isi perlu } \\
\text { direvisi(kurang layak) } \\
\text { Tidak valid dan perlu direvisi total } \\
\text { (tidak layak) }\end{array}$ \\
\hline
\end{tabular}

Angket respon peserta didik setelah menggunakan bahan ajar akan dianalisis secara deskriptif. Rumus yang digunakan untuk menghitung persentase angket adalah:

$$
\mathrm{P}=\frac{f}{N} \times 100 \%
$$

Keterangan :

$\mathrm{P}=$ Persentase respon peserta didik

$\mathrm{f}=$ Keseluruhan jawaban responden

$\mathrm{N}=$ Skor tertinggi dalam angket dikali jumlah responden

Tabel 2. Kriteria Respon Peserta Didik terhadap Desain Pembelajaran Alkena yang Telah Dikembangkan

\begin{tabular}{cc}
\hline $\begin{array}{c}\text { Interval } \\
\text { Presentase }\end{array}$ & Kriteria \\
\hline $83 \%$ s/d $100 \%$ & Sangat Tinggi \\
$67 \%$ s/d $83 \%$ & Tinggi \\
$51 \%$ s $/$ d $67 \%$ & Sedang \\
$35 \%$ s/d $51 \%$ & Rendah \\
$20 \%$ s/d $35 \%$ & Sangat Rendah \\
\hline
\end{tabular}

Hasil analisis data kemudian disesuaikan dengan angka kesepakatan hingga dapat ditentukan kriteria validitas dan angka tersebut sekaligus dapat menarik kesimpulan dari hasil analisis tersebut.

\section{HASIL DAN PEMBAHASAN}

Penelitian ini telah dilaksanakan di kelas XII IPA 1 SMA Negeri 1 Panyabungan. Penelitian ini dilaksanakan dengan beberapa tahapan yaitu a) analisis silabus sesuai kurikulum yang berlaku saat ini, (b) analisis 
buku dan multimedia oleh peneliti, (c) perancangan dan pengembangan bahan ajar dan multimedia, (d) validasi bahan ajar oleh dosen dan guru (e) validasi multimedia oleh dosen, dan (f) respon siswa terhadap bahan ajar yang dikembangkan.

Pada saat penelitian silabus yang digunakan disesuaikan dengan kurikulum yang berlaku saat ini yaitu kurikulum 2013. Tahap analisis silabus ini bertujuan untuk mengetahui submateri yang akan diajarkan pada materi senyawa alkena yaitu: (1) Kekhasan Atom Karbon, (2) Atom C Primer, Sekunder, Tersier, dan Kuartener, (3) Struktur dan Tata Nama Alkena, (4) Sifat Fisik dan Kimia Alkena, (5) Isomer, (6) Reaksi Senyawa Alkena. Berdasarkan analisis silabus yang telah dilakukan, maka diperoleh ada beberapa komponen sub materi yang tidak dipaparkan dalam silabus yaitu Pembuatan Alkena, Sumber Alkena di Alam, dan Kegunaan Alkena.

Selanjutnya dilakukan analisis lima buku kimia yang biasa digunakan di sekolah dengan kode buku (A, B, C, D, dan E). Analisis bahan ajar yang dilakukan khusus pada materi alkena dengan cakupan materi sebagai berikut: (1) Kekhasan Atom Karbon, (2) Atom C Primer, Sekunder, Tersier, dan Kuartener, (3) Struktur dan Tata Nama Alkena, (4) Sifat Fisik dan Kimia Alkena, (5) Isomer (6) Reaksi Alkena, (7) Pembuatan Alkena, (8) Sumber Alkena di Alam, dan (9) Kegunaan Alkena. Setelah kelima buku dianalisis dengan 9 cakupan materi tersebut, ditemukan beberapa kelebihan dan kelemahannya yaitu pada buku A ditemukan bahwa setiap komponen sub pokok materi terdapat contoh soal dan dilanjutkan dengan latihan soal, terdapat lembar kerja untuk percobaan yang akan dilakukan siswa secara berkelompok, terdapat tugas portofolio yang akan dilakukan siswa secara berkelompok, menyertakan info link yang dapat diakses siswa sehubungan dengan materi pelajaran kimia yang menarik, terdapat kuis dalam setiap bab, dan soal evaluasi yang di paparkan bervariasi. Buku B ditemukan bahwa setiap komponen sub pokok materi terdapat contoh soal dan dilanjutkan dengan review (latihan soal), terdapat lembar kerja untuk percobaan yang akan dilakukan siswa secara berkelompok, terdapat tugas proyek yang akan dilakukan siswa secara berkelompok, menyertakan info link yang dapat diakses siswa sehubungan dengan reaksi adisi pada alkena asimetris, dan soal evaluasi yang di paparkan bervariasi. Buku C ditemukan bahwa etiap komponen sub pokok materi terdapat contoh soal dan dilanjutkan dengan tugas (latihan soal), terdapat lembar kerja yang akan dilakukan siswa secara berkelompok, terdapat praktikum sederhana yang akan dilakukan siswa secara berkelompok, dan soal evaluasi yang di paparkan bervariasi. Buku D ditemukan bahwa setiap komponen sub pokok materi terdapat contoh soal dan dilanjutkan dengan tugas dan soal evaluasi yang di paparkan bervariasi. Dan buku E ditemukan bahwa setiap komponen sub pokok materi terdapat contoh soal dan dilanjutkan dengan latihan soal, terdapat lembar kerja untuk percobaan yang akan dilakukan siswa secara berkelompok, terdapat tugas portofolio yang akan dilakukan siswa secara berkelompok, menyertakan info link yang dapat diakses siswa sebagai penambah wawasan atau sumber bacaan, dan soal evaluasi yang di paparkan bervariasi. Sedangkan kelemahannya ditemukan bahwa buku A, B, dan $C$ belum memuat materi tentang pembuatan, sumber, dan kegunaan dari senyawa alkena. belum memuat materi tentang pembuatan dan sumber dari senyawa alkena. Buku D dan buku E belum memuat materi tentang pembuatan dan sumber dari senyawa alkena.

Selain itu dilakukan analisis buku kimia dengan instrumen BSNP untuk melihat kelayakan isi, kelayakan bahasa, kelayakan penyajian, dan kelayakan kegrafikan. Sehingga diperoleh hasil analisis dapat dilihat pada tabel 3. 
Tabel 3. Hasil Analisis Lima Buku Kimia Oleh Peneliti

\begin{tabular}{cccccc}
\hline \multirow{5}{*}{ Buku } & \multicolumn{3}{c}{ Rata-Rata Skor Standar } & Rata- \\
Teks & \multicolumn{4}{c}{ Kesesuaian Materi } & Rata \\
\cline { 2 - 4 } & I & B & P & K & \\
\hline $\begin{array}{c}\text { Buku } \\
\text { A }\end{array}$ & 3,45 & 3,53 & 3,52 & 3,45 & 3,48 \\
$\begin{array}{c}\text { Buku } \\
\text { B }\end{array}$ & 3,33 & 3,46 & 3,68 & 3,63 & 3,52 \\
$\begin{array}{c}\text { Buku } \\
\text { C } \\
\text { Buku } \\
\text { D }\end{array}$ & 3,25 & 3,13 & 3,15 & 3,18 & 3,17 \\
$\begin{array}{c}\text { Buku } \\
\text { E }\end{array}$ & 3,54 & 3,60 & 3,63 & 3,63 & 3,60 \\
$\begin{array}{c}\text { Rata- } \\
\text { Rata }\end{array}$ & 3,38 & 3,38 & 3,51 & 3,46 & 3,43 \\
\hline
\end{tabular}

Keterangan :

$\begin{array}{ll}\text { I } & \text { : Kelayakan Isi } \\ \text { B } & \text { : Kelayakan Bahasa } \\ \text { P } & \text { : Kelayakan Penyajian } \\ \text { K } & \text {; Kelayakan Kegrafikan }\end{array}$

Berdasarkan data di atas, dapat dilihat bahwa hasil analisis dari kelima buku kimia tersebut memiliki kelebihan dan kekurangan baik dari segi kelayakan isi, kelayakan bahasa, kelayakan penyajian, dan kelayakan kegrafikan. Hasil penilaian kelayakan isi, kelayakan bahasa, kelayakan penyajian, dan kelayakan kegrafikan terhadap kelima bahan ajar (buku kimia) memberikan hasil yang berbeda-beda.

Berdasarkan analisis multimedia diperoleh bahwa media yang digunakan sebelum dilakukan penelitian masih memiliki kekurangan. Media pembelajaran yang digunakan sudah terlalu lama salah satunya dengan menggunakan media dalam bentuk powerpoint dengan tampilan yang kurang menarik dan kurang update sehingga guru tidak bisa memberikan gambaran tentang teknologi di era sekarang ini. Sehingga ada baiknya untuk menambahkan media pembelajaran yang lebih menarik adalah dengan berbasis komputer dengan perpaduan berbagai multimedia.Tahapan selanjutnya adalah perancangan dan pengembangan bahan ajar berbasis proyek diambil dari beberapa fase pokok sebagai berikut: menganalisis silabus dan buku kimia yang memiliki pokok bahasan senyawa alkena dengan beberapa pengarang, kemudian hasil analisis silabus dan kelima buku kimia dari berbagai pengarang dijadikan bahan referensi untuk membuat bahan ajar berbasis proyek pada materi senyawa alkena. Pada bahan ajar berbasis proyek ini memuat cakupan materi sebagai berikut: : (1) Kekhasan Atom Karbon, (2) Atom C Primer, Sekunder, Tersier, dan Kuartener, (3) Struktur dan Tata Nama Alkena, (4) Sifat Fisik dan Kimia Alkena, (5) Isomer (6) Reaksi Alkena, (7) Pembuatan Alkena, (8) Sumber Alkena di Alam, dan (9) Kegunaan Alkena. Karena pada silabus dan kelima buku tersebut tidak menjelaskan tentang materi Pembuatan Alkena, Sumber Alkena di Alam, dan Kegunaan Alkena. Maka pada bahan ajar berbasis proyek yang dikembangkan terlihat adanya penyempurnaan pada cakupan materinya, yang tadinya tidak dijelaskan menjadi dijelaskan.

Selanjutnya dilakukan validasi terhadap bahan ajar dengan menggunakan angket BSNP yang telah dimodifikasi, dalam angket ini aspek yang dinilai meliputi aspek kelayakan isi, aspek kelayakan bahasa, aspek kelayakan penyajian, dan aspek kelayakan kegrafikan. Validasi dilakukan oleh validator ahli yang terdiri dari 3 dosen Kimia KDBK Organik dan 5 guru kimia SMA Negeri 1 Panyabungan. Hasil analisis bahan ajar oleh dosen dan guru kimia sesuai dengan standar BSNP dapat dilihat di bawah ini.

Tabel 4. Hasil Validasi Bahan ajar Sesuai BSNP Oleh Dosen KDBK Organik UNIMED

\begin{tabular}{|c|c|c|c|c|}
\hline \multirow{2}{*}{ Kompenen } & \multicolumn{3}{|c|}{ Penilaian } & \multirow{2}{*}{$\begin{array}{l}\text { Rata- } \\
\text { rata } \\
\text { Skor }\end{array}$} \\
\hline & D1 & $\mathrm{D} 2$ & D3 & \\
\hline Kelayakan Isi & 3,54 & 3,36 & 3,45 & 3,45 \\
\hline $\begin{array}{l}\text { Kelayakan } \\
\text { Bahasa }\end{array}$ & 3,6 & 3,53 & 3,8 & 3,64 \\
\hline $\begin{array}{l}\text { Kelayakan } \\
\text { Penyajian }\end{array}$ & 3,66 & 3,19 & 3,85 & 3,57 \\
\hline $\begin{array}{l}\text { Kelayakan } \\
\text { Kegrafikan }\end{array}$ & 3,54 & 2,90 & 3,90 & 3,45 \\
\hline Rata-Rata & 3,58 & 3,24 & 3,75 & 3,52 \\
\hline
\end{tabular}


Bahan ajar yang telah disusun telah divalidasi berdasarkan instrumen BSNP yang terdiri dari beberapa komponen seperti kelayakan isi, kelayakan bahasa, kelayakan penyajian, dan kelayakan kegrafikan. Adapun rata-rata analisis bahan ajar berbasis proyek yang telah dikembangkan adalah 3,52 yang berarti bahan ajar sudah valid dan tidak perlu direvisi dengan rata-rata penjabaran hasil validasi adalah kelayakan isi sebesar 3,45 kelayakan bahasa sebesar 3,64 kelayakan penyajian sebesar 3,57 dan kelayakan kegrafikan sebesar 3,45.

Bahan ajar berbasis proyek ini bukan hanya divalidasi oleh dosen, melainkan divalidasi juga oleh guru kimia yang mengajar di SMA Negeri 1 Panyabungan.. Hasil validasi dari guru kimia untuk bahan ajar sesuai standar BSNP dapat dilihat di bawah ini.

Tabel 5. Hasil Validasi Bahan ajar sesuai BSNP Guru Kimia SMA N 1 Panyabungan

\begin{tabular}{ccccccc}
\hline \multirow{2}{*}{ K } & \multicolumn{5}{c}{ Penilaian } & Rata- \\
\cline { 2 - 6 } & G1 & G2 & G3 & G4 & G5 & Rata \\
\hline I & 3,72 & 3,40 & 3,45 & 3,72 & 3,77 & 3,61 \\
B & 4 & 3,8 & 3,86 & 3,93 & 4 & 3,91 \\
P & 4 & 3,76 & 3,76 & 3,85 & 4 & 3,87 \\
K & 4 & 3,90 & 3,90 & 3,90 & 4 & 3,94 \\
Rata- & 3,93 & 3,71 & 3,74 & 3,85 & 3,94 & 3,83 \\
Rata & & & & & &
\end{tabular}

Keterangan Komponen (K) :

I : Kelayakan Isi

B : Kelayakan Bahasa

P : Kelayakan Penyajian

K Kelayakan Kegrafikan

Adapun rata-rata analisis bahan ajar yang telah dikembangkan adalah 3,83 yang berarti bahan ajar sudah valid dan tidak perlu direvisi dengan rata-rata penjabaran hasil validasi adalah kelayakan isi 3,61 kelayakan bahasa 3,91 kelayakan penyajian 3,87 dan kelayakan kegrafikan 3,94.

Bahan ajar divalidasi oleh dosen Kimia FMIPA UNIMED dan guru Kimia. Hasil validasi dari Dosen dan guru kimia dapat dilihat di bawah ini.
Tabel 6. Hasil Validasi Oleh Dosen dan Guru

\begin{tabular}{|c|c|c|c|c|}
\hline \multirow{2}{*}{ No } & \multirow{2}{*}{$\begin{array}{c}\text { Komponen } \\
\text { Penilaian }\end{array}$} & \multicolumn{2}{|c|}{ Penilaian } & \multirow{2}{*}{$\begin{array}{r}\text { Rata } \\
\text { Rata }\end{array}$} \\
\hline & & Dosen & Guru & \\
\hline 1 & Kelayakan Isi & 3,45 & 3,61 & 3,53 \\
\hline 2 & $\begin{array}{l}\text { Kelayakan } \\
\text { Bahasa }\end{array}$ & 3,64 & 3,91 & 3,77 \\
\hline 3 & $\begin{array}{l}\text { Kelayakan } \\
\text { Penyajian }\end{array}$ & 3,57 & 3,87 & 3,72 \\
\hline 4 & $\begin{array}{l}\text { Kelayakan } \\
\text { Kegrafikan }\end{array}$ & 3,45 & 3,94 & 3,69 \\
\hline \multicolumn{2}{|c|}{ Rata-Rata } & 3,52 & 3,83 & 3,67 \\
\hline
\end{tabular}

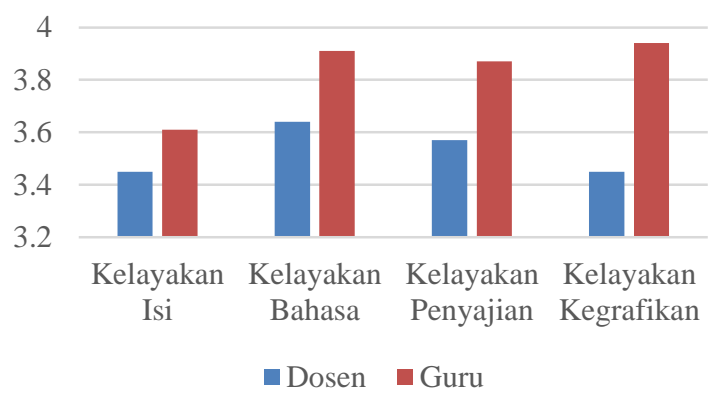

Gambar 1. Penilaian Bahan ajar Oleh Dosen Kimia dan Guru Kimia

Berdasarkan hasil validasi bahan ajar berbasis proyek diperoleh rata-rata penilaian dari validator berdasarkan kelayakan isi sebesar 3,53 kelayakan bahasa sebesar 3,77 kelayakan penyajian sebesar 3,72 kelayakan kegrafikan sebesar 3,69. Sesuai dengan kriteria validitas rata-rata BSNP, angka tersebut berada pada kisaran 3,26-4,00 yang berarti bahan bahan ajar berbasis proyek pada materi Senyawa Alkena telah valid dan tidak perlu direvisi. Sehingga, bahan ajar ini layak dan dapat digunakan dalam proses pembelajaran.

Kemudian dilakukan validasi multimedia dengan menggunakan angket penilaian BSNP yang telah dimodifikasi. Validasi dilakukan oleh validator ahli yang terdiri dari 2 dosen Kimia FMIPA UNIMED. Berdasarkan hasil validasi multimedia sebagai pengantar tugas proyek diperoleh rata-rata penilaian dari validator sebesar 3,77. Sesuai dengan kriteria validitas rata-rata BSNP, angka tersebut berada pada kisaran 3,26-4,00 yang berarti multimedia sebagai pengantar tugas proyek pada materi Senyawa Alkena telah valid dan tidak perlu direvisi. Sehingga, 
multimedia ini layak dan dapat digunakan dalam proses pembelajaran.

Setelah bahan ajar dan multimedia valid maka peneliti meminta kepada siswa untuk merespon bahan ajar berbasis proyek dengan multimedia yang dikembangkan dengan tujuan untuk melihat persentasi tingkat kepuasan siswa pada aspek tampilan, aspek materi, dan aspek manfaat. Diperoleh hasil dari 20 orang responden yaitu aspek tampilan sebesar $90,4 \%$, aspek materi sebesar $89,9 \%$, dan aspek manfaat sebesar 90,7\%. Sehingga rata-rata persentasi tingkat kepuasaan siswa terhadap bahan ajar berbasis proyek dengan multimedia yang sudah dikembangkan sebesar 90,33\%. Hal ini membuktikan bahwa siswa menyukai bahan ajar dengan multimedia tersebut sehingga bahan ajar dapat digunakan dalam pembelajaran kimia serta sebagai referensi bacaan bagi siswa.

Terdapat banyak faktor yang mempengaruhi siswa agar lebih fokus dalam belajar yang akhirnya dapat meningkatkan hasil belajar siswa seperti bahan ajar, model pembelajaran, suasana kelas, dan media pembelajaran yang digunakan. Pembelajaran berbasis proyek merupakan pendekatan, strategi atau metode pembelajaran yang berpusat pada siswa, bersifat antara disiplin ilmu (integrasi mata pelajaran), dan berjangka panjang. Pembelajaran berbasis proyek memiliki karakteristik yang dapat mengembangkan kemampuan berpikir siswa, memungkinkan mereka untuk memiliki kreatifitas, mendorong mereka untuk saling kerja sama, dan mengarahkan mereka untuk mengakses informasi secara mandiri dan untuk menunjukkan informasi, sehingga dapat meningkatkan motivasi dan hasil belajar siswa.

Menurut penelitian (Aloina, 2020) membuktikan bahwa dengan pengembangan modul pembelajaran kimia akan memberikan dampak positif terhadap tingkat kepuasaan siswa yang terbukti dari respon siswa yang menunjukkan nilai yang tinggi. Selain itu hasil penelitian (Islamiyah, 2019) membuktikan pembelajaran berbasis proyek terintegrasi dalam bahan ajar dengan multimedia dalam pembelajaran kimia dikatakan dapat meningkatkan hasil belajar siswa pada materi alcohol dan eter. Dimana berdasarkan penelitiannya diperoleh nilai rata-rata gain 0,75 pada kelas eksperimen dan 0,77 pada kelas pengulangan yang mana dari kedua nilai rata-rata tersebut tergolong kriteria tinggi.

Maka berdasarkan hasil penelitian yang telah dilakukan dapat disimpulakan bahwa bahan ajar berbasis proyek dengan multimedia pada materi alkena ini telah valid dan tidak perlu direvisi serta respon siswa yang tinggi menunjukkan bahwa siswa menyukai bahan ajar tersebut dan bahan ajar dapat digunakan dalam pembelajaran kimia serta sebagai referensi bacaan bagi siswa.

\section{DISKUSI}

Setelah dilakukan validasi kepada validator ahli baik itu bahan ajar berbasis proyek maupun multimedia pengantar tugas proyek maka diperoleh bahwa bahan ajar berbasis proyek dengan multimedia dikatakan valid dan tidak perlu direvisi. Selain itu dengan respon siswa yang tinggi menunjukkan bahwa siswa menyukai bahan ajar dengan multimedia tersebut dan dapat dijadikan sebagai bahan ajar dalam pembelajaran kimia serta referensi bacaan bagi siswa.

\section{KESIMPULAN}

Berdasarkan penelitan yang dilakukan dapat diketahui bahan ajar berbasis proyek dengan multimedia pada materi alkena yang telah dikembangkan sudah memenuhi kelayakan BSNP dan multimedia sebagai pengantar tugas proyek juga layak digunakan untuk memudahkan siswa memahami tugas proyek yang ada pada bahan ajar. Hal ini juga sejalan dengan respon siswa yang menyatakan sangat puas dengan bahan ajar yang telah dikembangkan. 


\section{DAFTAR PUSTAKA}

Aloina, F. (2020). Pengembangan Modul Pembelajaran Kimia Berbasis Proyek Untuk Kelas X SMA Pada Pokok Bahasan Ikatan Kimia Sesuai Kurikulum 2013. Universitas Negeri Medan.

Andi Achmad. (2017). Hubungan Pengembangan Bahan Ajar Dan Media Pembelajaran Dengan Hasil Belajar Siswa Pada Mata Pelajaran Pendidikan Agama Islam Di Sekolah Dasar Negeri Kecamatan Sungai Kunjang. Syamil, 5(1), 59-73.

Handono Warih, A. J., Catur Saputro, A. N., \& Masykuri, M. (2015). Pembelajaran Kimia Menggunakan Model Numbered Heads Together (Nht) Disertai Media Kartu Pintar Dan Lks Terhadap Prestasi Belajar Siswa Pada Materi Pokok Termokimia Kelas Xi Sma N 1 Karanganyar Tahun Pelajaran 2013/2014. Jurnal Pendidikan Kimia, 4(2), 98-107.

Islamiyah, K. (2019). Pengembangan Bahan Ajar Berbasis Proyek dengan Multimedia pada Materi Aldehid dan Keton di Sekolah Menengah Atas. Universitas Negeri Medan.

Mawar, M., Purwaning, I., \& Hidayah, F. F. (2019). Universitas Muhammadiyah Semarang Universitas Muhammadiyah Semarang email : fitriafatichatul@unimus.ac.id.320-326.

Nurrita, T. (2018). Pengembangan Media Pembelajaran Untuk Meningkatkan Hasil Belajar Siswa. MISYKAT: Jurnal Ilmu-Ilmu Al-Quran, Hadist, Syari'ah Dan Tarbiyah, 3(1), 171. https://doi.org/10.33511/misykat.v3n1.1 71

Panggabean, F. T. M., \& Harahap, M. F. (2020). Analisis Problem Based Learning dan Discovery Learning menggunakan Macromedia Flash pada materi Termokimia. Jurnal Inovasi Pembelajaran Kimia, 2(2), 58. https://doi.org/10.24114/jipk.v2i2.19391

Purba, J., \& Siregar, N. (2020).
Pengembangan Bahan Ajar Berbasis Proyek Di SMA Negeri 2 Lintongnihuta pada materi Asam dan Basa. Jurnal Inovasi Pembelajaran Kimia, 2(2), 110. https://doi.org/10.24114/jipk.v2i2.19619

Purba, J., Situmorang, M., \& Silaban, R. (2019). The development and implementation of innovative learning resource with guided projects for the teaching of carboxylic acid topic. Indian Journal of Pharmaceutical Education and Research, 53(4), 603-612. https://doi.org/10.5530/ijper.53.4.121

Rati, N. W., Kusmaryatni, N., \& Rediani, N. (2017). Model Pembelajaran Berbasis Proyek, Kreativitas dan Hasil Belajar Mahasiswa. JPI: Jurnal Pendidikan Indonesia, 6(1), 60-71.

Singarimbun, E., Silaban, R., Suyanti, R. D., \& Siti, I. (2015). Pengembangan Bahan Ajar Kimia Inovatif pada Pokok Bahasan Reduksi dan Oksidasi Berdasarkan Kurikulum 2013 Terintegrasi Pendidikan Karakter. Jurnal Pendidikan Kimia Universitas Negeri Medan, 7(2), 13-20.

Sitaresmi, K., Saputro, S., \& Utomo, S. (2017). Penerapan Pembelajaran Project Based Learning (Pjbl) Untuk Meningkatkan Aktivitas Dan Prestasi Belajar Siswa Pada Materi Sistem Periodik Unsur (Spu) Kelas X Mia 1 Sma Negeri 1 Teras Boyolali Tahun Pelajaran 2015/2016. Jurnal Pendidikan Kimia, 6(1), 54-61.

Suharsimi, A. (2013). Dasar-Dasar Evaluasi Pendidikan. Bumi Aksara.

Suranti, N. M. Y., Gunawan, G., \& Sahidu, H. (2017). Pengaruh Model Project Based Learning Berbantuan Media Virtual Terhadap Penguasaan Konsep Peserta didik pada Materi Alat-alat Optik. Jurnal Pendidikan Fisika Dan Teknologi, 2(2), 73.

https://doi.org/10.29303/jpft.v2i2.292

Sutirman. (2013). Media \& Model-Model Pembelajaran Inovatif. Graha Ilmu. 